\title{
Characterization of Calcium Carbonate Extracted from Eggshell Waste at Various Calcination Temperature
}

\author{
M. I. Najah ${ }^{1}$, Aisyah Razak ${ }^{2}$, Nor Aida Che Shukur Nekmat ${ }^{3}$, Sharifah Adzila ${ }^{4}$, Raudhah Othman ${ }^{5}$, \\ Normayati Nordin ${ }^{6}$ \\ 1,2,3,4,5,6 Faculty of Mechanical \& Manufacturing Engineering, Universiti Tun Hussein Onn, Malaysia, \\ ${ }^{1}$ najahanismatisa@gmail.com \\ ${ }^{2}$ sitiaisyahrazak94@gmail.com \\ ${ }^{3}$ noraidacheshukur@gmail.com \\ ${ }^{4}$ adzila@uthm.edu.my \\ 5 raudha@uthm.edu.my \\ ${ }^{6}$ mayati@uthm.edu.my
}

\begin{abstract}
An efficient method to waste utilization is to successfully transform it into high value products. Chicken eggshell contain potential useful minerals of calcium carbonate in which can be processed into biomaterials used in biomedical application. The objective of this study is to derived calcium carbonate from eggshell and analyze the effect of various calcination temperatures on the properties of calcium carbonate. Fourier transform infrared (FTIR) spectroscopy indicates that all calcined samples reveals calcium carbonate is no longer present after calcination as it is already converted to calcium oxide. This also supported by $\mathrm{x}$-ray diffraction (XRD) graphs notably on $900^{\circ} \mathrm{C}$. Scanning electron microscopy (SEM) and particle size analysis are applied to determine morphological properties and mean sizes of particles for both raw and calcined samples.
\end{abstract}

Key words: Calcined, calcium carbonate, eggshell, extraction.

\section{INTRODUCTION}

The conversion of waste specifically from daily use and food industry into some useful product seems to be impossible and almost no value. Considering sustainable development, wastes should be recycled, reused and channeled towards the production of value added products. Normally at home, eggshells can easily be composted or sprinkled on flower beds as a snail and slug deterrent or soil enhancer. However, for poultry and egg production companies, shells have to be disposed in landfills because the waste egg attached to them rots quickly thus, lead to a smelly by-product. According to a report [1], regulation requires the disposal of eggshells to be heat treated to prevent it to become a source of disease towards humans, animals and vegetation. Hence, the industrial egg producers have developed a way in which eggshells and trays are incinerated together at a temperature around $1000 \square$ (the trays forming the fuel to burn the shells) resulting burnt limestone. Rather than worthless ash from incineration, burnt limestone turn out have potential as pozzolan served in production of high strength and high performance of building materials [2]-[4]. The process turns waste products into a valuable material, while the process energy is exploited in the production [5].

Eggshell is made of calcium carbonate like chalk, with a hard-wearing, crystalline structure. In addition, other studies revealed that eggshell to be in rich source for calcium from calcium carbonate which potentially can be served as useful raw materials for hydroxyapatite production in biomedical engineering. Besides, it is also found to be crucial as a biomaterial due to its osteophilic nature and its incorporation into bone tissues [6]-[9]. The advancement of biomaterials is carried out as a result of growing in the number of patients that requires medical and dental therapy. The production of this novel practice is expected to have successfully improved conventional clinical treatments and healing process. Natural bone is made up from inorganic and organic composite mainly nanostructure hydroxyapatite $\left(\mathrm{Ca}_{10}\left(\mathrm{PO}_{4}\right)_{6}(\mathrm{OH})_{2}\right)$ or known as HAp and collagen fibers. Hydroxyapatite have similar chemical composition and biological affinity to the mineral component of bone. Bone mineral is a salt where the ratio of calcium to phosphate $(\mathrm{C} / \mathrm{P})$ is $1.5-1.7$ whereas hydroxyapatite $\mathrm{C} / \mathrm{P}$ ratio is generally assumed to be 1.67 which is within the range [10]-[12]. Hydroxyapatite is among of the few materials that are classified as bioactive, implies that it will support bone ingrowth along with osseointegration when used in orthopaedic [13]. 
Calcium carbonate $\left(\mathrm{CaCO}_{3}\right)$ from eggshell can be converted into calcium oxide $(\mathrm{CaO})$ by way of calcination process. $\mathrm{CaO}$ has proved to be the active phase in the eggshells and the adequate temperature for calcination process must be above $800 \square$ [14]. Obtaining $\mathrm{CaO}$ is essential as it is a raw material for producing calcium phosphate or hydroxyapatite that will be further synthesized by means of various synthesis method such as precipitation, sol gel, etc. in manufacturing of scaffolds or any other biomedical needs [15]-[18]. Up to date, eggshell can serve as a promising biomaterials source because of its continuous resource compare to other natural sources of hydroxyapatite like bovine bones and corals.

This research work focused on the calcification chicken eggshells as the main source of calcium carbonate. The chemical and physical properties of the materials (uncalcined and calcined) as well as morphological were studied.

\section{MATERIALS \& METHOD}

\subsection{Sample preparation}

Eggshell waste (EW) is collected from restaurants close proximity within Universiti Tun Hussein Onn main campus, Parit Raja, Johor, Malaysia. Later, the eggshells were cleaned and immersed in boiling water for 30 minutes to remove interference material and impurity on EW. Next, it being dry for 4 hours at temperature $100^{\circ} \mathrm{C}$ in oven and being crush to small size of flakes. The dry $\mathrm{EW}$ were calcined at four different temperature $\left(600,700,800\right.$ and $\left.900^{\circ} \mathrm{C}\right)$ for 4 hours with normal increment and decrement of calcification temperature profile. Next, all calcined sample and uncalcined sample were crush to size $<40 \mu \mathrm{m}$ using mortar and sieve. All sample were kept in drying box to avoid any reaction from air humidity and carbon dioxide $\left(\mathrm{CO}_{2}\right)$.

\subsection{Characterization}

Uncalcined EW along with all calcined samples were analyzed by Particle Size Analyzer (PSA), Fourier transformed Infrared Spectroscopy (FTIR), X-Ray Diffraction (XRD) and Scanning Electron Microscope (SEM) with combination of Energy Dispersive X - Ray (EDX). All samples with size $<40 \mu \mathrm{m}$ were analyzed using PSA to obtain mean size distribution for every samples. For FTIR, IR spectra of every samples were recorded using ATR technique (range $4000-600 \mathrm{~cm}^{-1}$ ) to find it functional group. For phase analysis by XRD, the range of diffraction angle $2 \Theta$ is $10^{\circ}$ $90^{\circ}$ using radiation source of $\mathrm{Cu} \mathrm{K} \alpha$ radiation $(\lambda=1.5406 \AA)$. Morphology of all samples were characterized using SEM with magnification 50X (low magnification) and 3000X (high magnification). To find the percentage composition of sample, EDX was combine with SEM. For SEM characterization, all samples were double coated by gold using sputter coater to creating conductive layer.

\section{RESULTS \& DISCUSSIONS}

\subsection{Visual observation}

The appearance of compound as the results of calcification on EW is one of the first qualitative analysis were analyzed. Heating a compound can cause liquid inside the samples to condensed. When strongly heated, calcium carbonate from eggshells undergoes thermal decomposition to yield calcium oxide and carbon dioxide gas via the reaction (1) below:

$$
\mathrm{CaCO}_{3} \rightarrow \mathrm{CaO}+\mathrm{CO}_{2}
$$

In addition to that, eggshell waste experienced changes in color as calcination temperature rises up to $900 \square$. Figure 1 shows color transition from uncalcined eggshell to calcined eggshell from $600 \square$ to $900 \square$. Color transition is due to a change in crystalline phase and structure [19], [20]. By enforcing heat to some substances, it can causes chemical changes or chemical reactions wherein one or more new substances are formed (with distinct properties from the original).

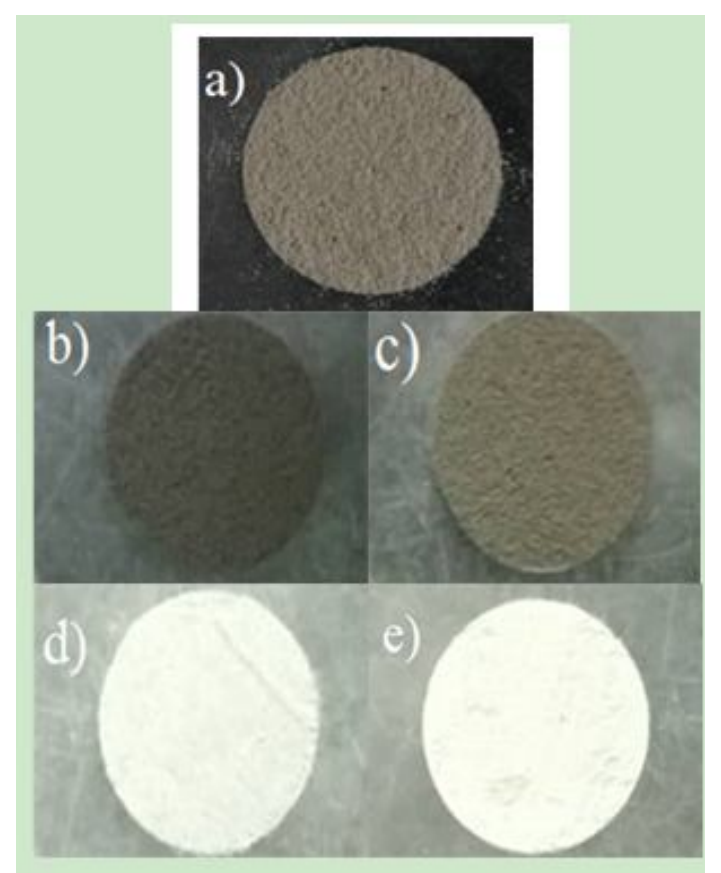

Figure 1: Calcined samples of EW from (a) Uncalcined (reference sample), (b) $600 \square$, (c) $700 \square$,(d) $800 \square$, (e) $900 \square$

It can be observed that from temperature of $600 \square$, the samples color was darker and eventually turns white at the highest calcination temperature of $900 \square$. The thermal decompositon of eggshell carried out by means of two mass-loss processes: first, the primary thermal degradation of the outer shell membrane and second, the subsequent thermal decomposition of calcite in the shell matrix [21]. In addition to that, a higher calcination temperature produced odorless and more softest powder compare to uncalcined eggshell that 
M. I. Najah et al., International Journal of Emerging Trends in Engineering Research, 8(10), October 2020, $6725-6731$

give off stinky smell and more of hard and flakes powder. Table 1 below summarized the physical characterization of all samples.

Table 1: Physical observation of uncalcined and calcined EW

\begin{tabular}{|c|c|c|c|}
\hline \multirow{2}{*}{$\begin{array}{c}\text { Temperatu } \\
\text { re }\left({ }^{\circ} \mathrm{C}\right)\end{array}$} & \multicolumn{3}{|c|}{ Physical characterization } \\
\cline { 2 - 4 } & $\begin{array}{c}\text { Color } \\
\text { light brown }\end{array}$ & Odor & Softness \\
\hline 0 & Black & Stink & $\begin{array}{c}\text { Hard, } \\
\text { flakes }\end{array}$ \\
\hline 600 & $\begin{array}{c}\text { Black } \\
\text { powder }\end{array}$ \\
\hline 700 & Solid gray & Taint & $\begin{array}{c}\text { Softer, } \\
\text { powder }\end{array}$ \\
\hline 800 & White & Odoint & $\begin{array}{c}\text { Softer, } \\
\text { powder }\end{array}$ \\
\hline 900 & & $\begin{array}{c}\text { Softest, } \\
\text { powder }\end{array}$ \\
\hline
\end{tabular}

\subsection{Particle Size Analysis}

The particle size analysis (PSA) of the uncalcined and calcined EW were characterized by using Fritsch particle sizer model 'analysette 22'. In this part, PSA provided us with information of mean sizes in which similar to the concept of average. Figure 2 shows graph of calcination temperature versus particle size of uncalcined and calcined EW samples.

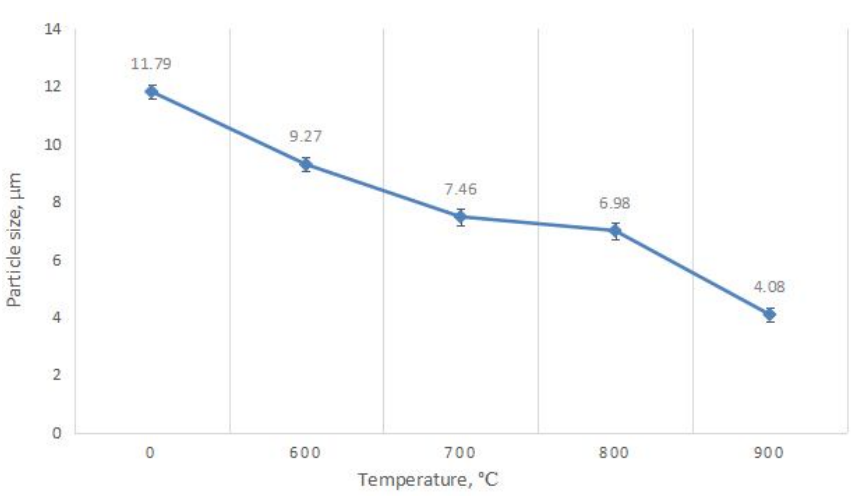

Figure 2: Mean sizes of uncalcined and calcined eggshell versus various calcination temperature

In accordance to the plotted PSA graph above, it can be considered that increasing of calcination temperature resulting considerable decreasing of the particle size of samples. Mean size of uncalcined EW displays to be on $11.79 \mu \mathrm{m}$ and continue to climbing down slowly at first calcination temperature of $600 \square$ with mean size of $9.27 \mu \mathrm{m}$, then continue to mean particle size of $7.46 \mu \mathrm{m}, 6.98 \mu \mathrm{m}$ then eventually to $4.08 \mu \mathrm{m}$ at the highest calcination temperature of $900 \square$. Calcification to turn calcium carbonate to calcium oxide is considered as physical method where calcium oxide nanoparticles were obtained owing to the evaporation of the gaseous $\mathrm{CO}_{2}$. Researcher [22] also claimed that the diameter of calcined particles will drastically decreased with increasing in temperature.

\subsection{Chemical Bonding Analysis}

Fourier transform infrared (FTIR) spectrometry was analyzed to determine the functional group of both simultaneously raw and calcined EW. According to the results in Figure 3, it shows the IR spectra of both raw and calcined EW. The IR spectra before calcination, that represent uncalcined EW displays that the sharp band at around $710 \mathrm{~cm}^{-1}$. In common with IR spectra of EW calcined at $600 \square, 700 \square, 800 \square$ and blunt peak at $900 \square$ this can be representing to a $\mathrm{Ca}-\mathrm{O}$ bond with which supported by [23]-[26] who observed similar band ranges for calcium carbonate, $\mathrm{CaCO}_{3}$ study in eggshells. Next, IR spectra of uncalcined EW displays sharp band at around $875 \mathrm{~cm}^{-1}$ and a wide stretching peak at around 1415 $\mathrm{cm}^{-1}$ represent the $\mathrm{C}-\mathrm{O}$ stretching and bending of $\mathrm{CaCO}_{3}$. A broad transmission band around $1700 \mathrm{~cm}^{-1}$ can be referred to $\mathrm{OH}$ stretching vibration or carbonate mineral vibrations modes from residual waste.

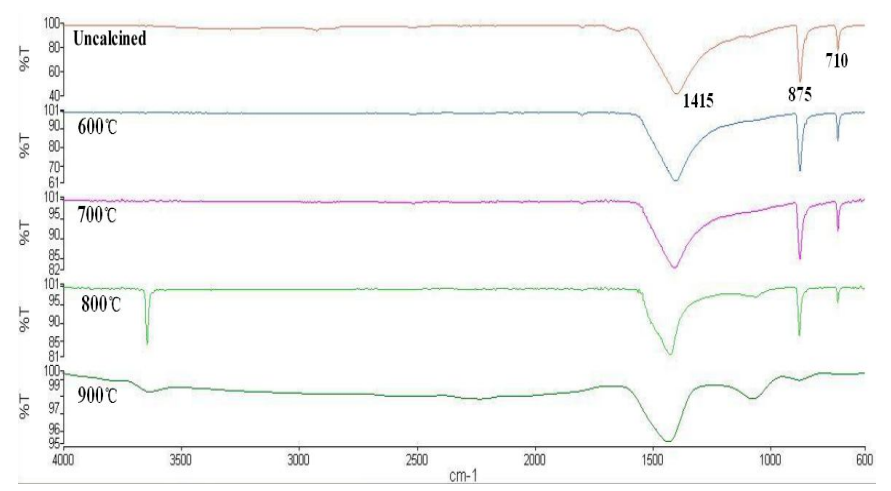

Figure 3: FTIR spectra of raw (uncalcined) and calcined EW

IR spectra after calcination, displays there is presence of $\mathrm{OH}$ in $\mathrm{Ca}(\mathrm{OH})_{2}$ at the peak around $3600 \mathrm{~cm}^{-1}$. This matches to $\mathrm{OH}$ stretching during adsorption of water by $\mathrm{CaO}$. Next, another band existence at around $875 \mathrm{~cm}^{-1}$ as regards to identified vibration of the $\mathrm{Ca}-\mathrm{O}$ bond. Lastly, there is sharp absorption region at around $1600 \mathrm{~cm}^{-1}, 1415 \mathrm{~cm}^{-1}$ and 1398 $\mathrm{cm}^{-1}$ which signifies functional groups present in eggshell where $\mathrm{CO}_{2}^{2-}$ vibrates. It also indicates that $\mathrm{CaCO}_{3}$ was no longer present as it already converted to $\mathrm{CaO}$. [24] added that, general reduction in intensity of the IR spectra peaks in the raw eggshells signified that most of the functional groups were destroyed during heat treatment.

\subsection{Phase Analysis}

Figure 4 shows XRD pattern of uncalcined and calcined EW at different temperature. From the pattern of graph, it shows that every graph have different diffraction pattern due to temperature change in calcination process. 
M. I. Najah et al., International Journal of Emerging Trends in Engineering Research, 8(10), October 2020, $6725-6731$

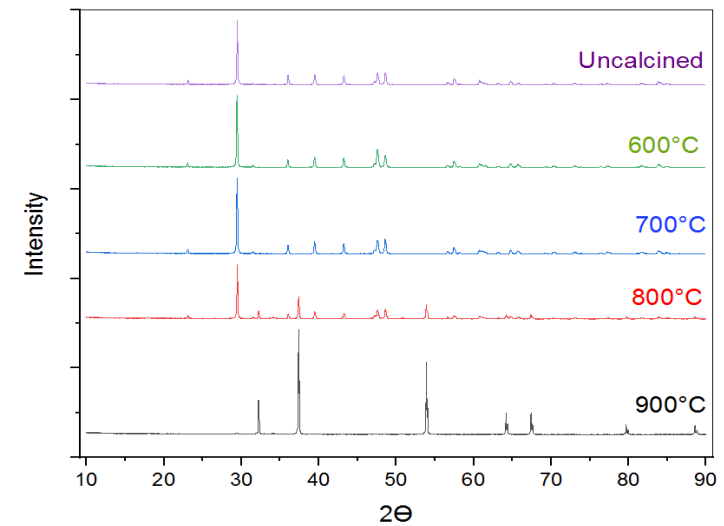

Figure 4: XRD pattern of uncalcined EW and calcined EW at $600,700,800$ and $900^{\circ} \mathrm{C}$

Uncalcined EW and other calcination temperature of EW diffraction pattern shows small change in it pattern. This occur due to the presence of $\mathrm{CaCO}_{3}$ in other sample except $900^{\circ} \mathrm{C}$ [27]. $\mathrm{CaCO}_{3}$ is appear at all diffraction peak of uncalcined $\mathrm{EW}$ while no $\mathrm{CaO}$ peak detected at uncalcined sample as major compound in pure eggshell is $\mathrm{CaCO}_{3}[28]$. For 600 and $700^{\circ} \mathrm{C}$ calcination of EW, all peak still shows $\mathrm{CaCO}_{3}$ phase. So, both this temperature is not suitable to use in $\mathrm{CaO}$ production. At $800^{\circ} \mathrm{C}, \mathrm{CaO}$ peak starting to appear. However, $\mathrm{CaCO}_{3}$ peak still shows high intensity rather than $\mathrm{CaO}$ peak. This temperature still cannot be considering as suitable temperature to use in $\mathrm{CaO}$ processing as it still has high $\mathrm{CaCO}_{3}$ compound in it sample. But from this temperature, it can be concluding that $800^{\circ} \mathrm{C}$ is the starting temperature for $\mathrm{CaCO}_{3}$ transform to $\mathrm{CaO}$. Diffraction pattern of $900^{\circ} \mathrm{C}$ shows major different when no phase of $\mathrm{CaCO}_{3}$ detected. All peak in in this temperature successfully transform to $\mathrm{CaO}$ completely. So, this temperature is suitable to use for $\mathrm{CaO}$ production as it successfully turns to $\mathrm{CaO}$ without leaving any peak of $\mathrm{CaCO}_{3}$.

The peaks existence was referred to the Joint Committee on Powder Diffraction Standards (JCPDS) data of $\mathrm{CaO}$ (PDF Card No. 99-0070) and $\mathrm{CaCO}_{3}$ (PDF Card No. 00-081 2027) [27], [29]. The phase existence is summarizing in Table 2.

Table 2: XRD data of $\mathrm{CaO}$ and $\mathrm{CaCO}_{3}$ from JCPDS, uncalcined and calcined $\mathrm{EW}$ at various temperature

\begin{tabular}{|c|c|c|c|c|c|c|}
\hline Sample & Compound & $2 \theta$ & & & & \\
\hline \multirow[t]{4}{*}{ JCPDS } & $\mathrm{CaO}$ & 32.2 & 37.3 & 58.3 & 64.1 & 67.3 \\
\hline & $\mathrm{CaCO}_{3}$ & & & & & \\
\hline & & 29.4 & 39.4 & 43.2 & 47.4 & 48.5 \\
\hline & & $\circ$ & $\circ$ & $\circ$ & & \\
\hline \multirow[t]{2}{*}{ Uncalcined } & $\mathrm{CaO}$ & - & - & - & - & - \\
\hline & $\mathrm{CaCO}_{3}$ & $\begin{array}{l}29.5 \\
\circ\end{array}$ & $\begin{array}{l}39.4 \\
\circ\end{array}$ & $\begin{array}{l}43.2 \\
\circ\end{array}$ & $\begin{array}{l}47.5 \\
\circ\end{array}$ & $\begin{array}{l}48.8 \\
\circ\end{array}$ \\
\hline \multirow[t]{2}{*}{$600 \square$} & $\mathrm{CaO}$ & - & - & - & - & - \\
\hline & $\mathrm{CaCO}_{3}$ & $\begin{array}{l}29.5 \\
\circ\end{array}$ & $\begin{array}{l}39.5 \\
\circ\end{array}$ & $\begin{array}{l}43.1 \\
\circ\end{array}$ & $\begin{array}{l}47.7 \\
\circ\end{array}$ & $\begin{array}{l}48.7 \\
\circ\end{array}$ \\
\hline \multirow[t]{2}{*}{$700 \square$} & $\mathrm{CaO}$ & - & - & - & - & - \\
\hline & $\mathrm{CaCO}_{3}$ & 29.5 & 39.5 & 43.1 & 47.4 & 48.5 \\
\hline
\end{tabular}

\begin{tabular}{lllllll}
\hline & & $\circ$ & $\circ$ & $\circ$ & $\circ$ & $\circ$ \\
\hline $800 \square$ & $\mathrm{CaO}$ & 32.3 & 37.4 & 54.1 & 64.4 & 67.4 \\
& $\mathrm{CaCO}_{3}$ & $\circ$ & $\circ$ & $\circ$ & $\circ$ & $\circ$ \\
& & 29.5 & 39.6 & 43.2 & 47.3 & 48.8 \\
& & $\circ$ & $\circ$ & $\circ$ & $\circ$ & $\circ$ \\
\hline $900 \square$ & $\mathrm{CaO}$ & 32.2 & 37.4 & 53.8 & 64.1 & 67.3 \\
& $\mathrm{CaCO}_{3}$ & $\circ$ & $\circ$ & $\circ$ & $\circ$ & $\circ$ \\
& & - & - & - & - & - \\
& & & & $\circ$
\end{tabular}

Based on the comparison in Table 2, all the diffraction peak that achieve from the sample is nearly similar to JCPDS data. This shows that the result of this experiment is valid due to the diffraction value that in range of JCPDS data. From this table, the statement from XRD pattern above is supported with this data where uncalcined and calcined EW at 600 and $700^{\circ} \mathrm{C}$ only have $\mathrm{CaCO}_{3}$ while at temperature $800^{\circ} \mathrm{C} \mathrm{CaCO}_{3}$ and $\mathrm{CaO}$ peak both present. Lastly, $900^{\circ} \mathrm{C}$ temperature of calcination is proved contain only $\mathrm{CaO}$ in diffraction angle that suit JCPD data [27], [29]. So, $900^{\circ} \mathrm{C}$ is confirmed to be used for $\mathrm{CaO}$ processing temperature without any impurities.

\subsection{Morphological Analysis}

The apparent morphologies of uncalcined and calcined EW at different temperature examined by SEM are shown in Figure 5. Based on the image, it shows that when temperature increase, the size of particle decrease. This trend can be seen from Figure 5 (a) to Figure 5 (e) where uncalcined EW have large particle size and start to decrease when temperature increase. This trend follows PSA result where uncalcined EW have highest mean particle size while calcined $\mathrm{EW}$ at $900^{\circ} \mathrm{C}$ have smallest size of particle. At magnification 50X, uncalcined $\mathrm{EW}, 600^{\circ} \mathrm{C}$ and $700^{\circ} \mathrm{C}$ shows shape of particles with edges or like irregular flakes shape. At high magnification, this three sample look like concrete stone shape. For sample $800^{\circ} \mathrm{C}$ at low magnification, it changes to shape without edges. At high magnification, it starts to create different shape from temperature before. At temperature $900^{\circ} \mathrm{C}$, the EW powder become finer at low magnification as can see at Figure 5 (e). At high magnification, shape of sample changed to interconnect like skeleton shape from irregular flakes shaped [23]. Increasing of heat caused the structure of EW change it shape.

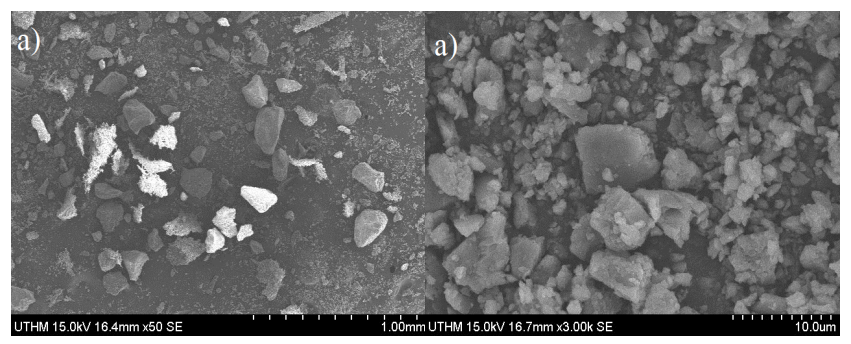




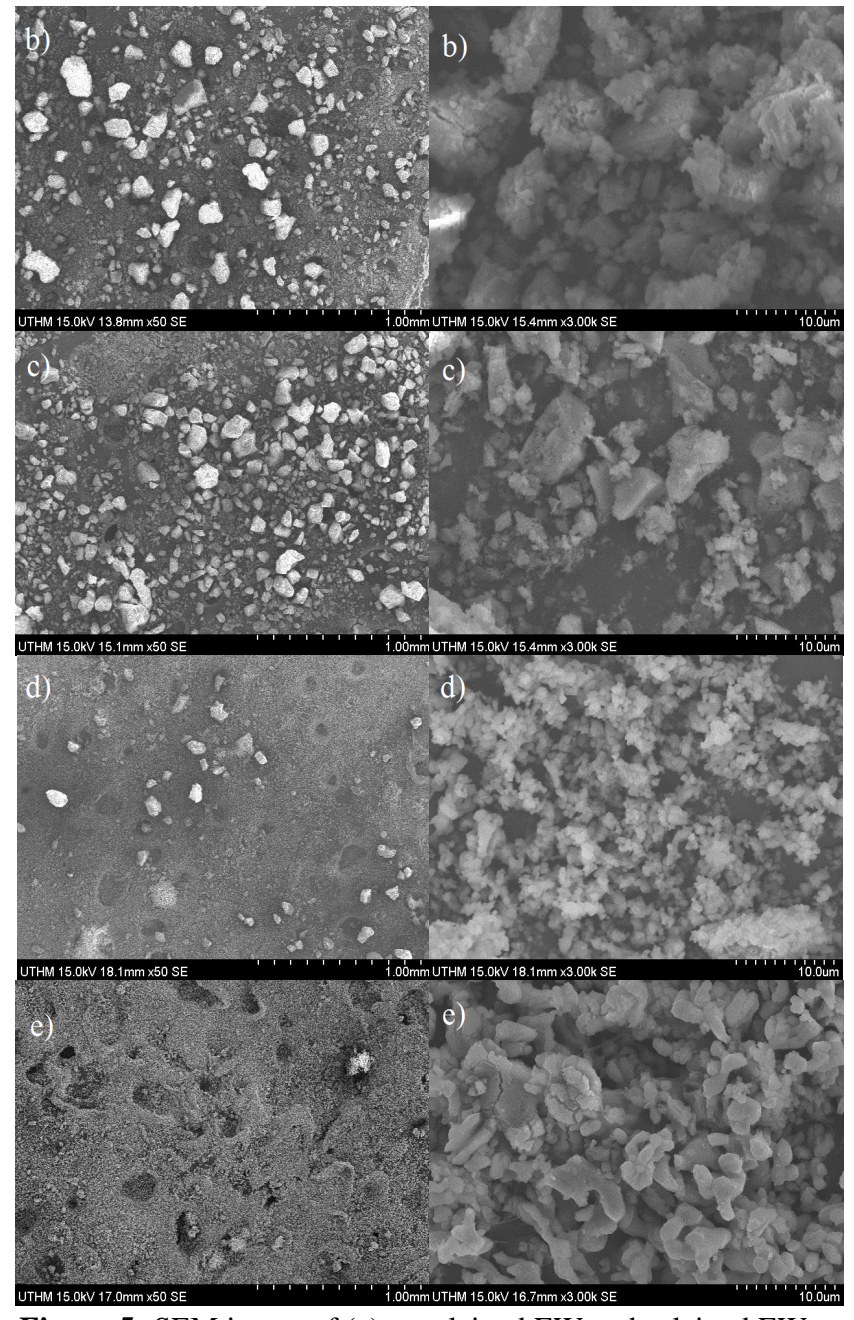

Figure 5: SEM image of (a) uncalcined EW and calcined EW at temperature (b) 600, (c) 700, (d) 800 and (e) $900^{\circ} \mathrm{C}$ (left) $50 \mathrm{X}$ and (right) $3000 \mathrm{X}$

For EDX result, all sample were testing and it result shown in Table 3 below.

Table 3: EDX data of C.O, and Ca for uncalcined and calcined sample at different temperature.

\begin{tabular}{llll}
\hline Sample & Element & Weight $\%$ & Atomic \% \\
\hline \multirow{3}{*}{ Uncalcined } & Carbon, C & 29.76 & 41.55 \\
\cline { 2 - 4 } & Oxygen, $\mathrm{O}$ & 46.12 & 48.35 \\
\cline { 2 - 4 } & Calcium, Ca & 24.12 & 10.09 \\
\hline $600^{\circ} \mathrm{C}$ & Carbon, $\mathrm{C}$ & 24.28 & 35.36 \\
\cline { 2 - 4 } & Oxygen, $\mathrm{O}$ & 48.11 & 52.59 \\
\cline { 2 - 4 } & Calcium, Ca & 27.61 & 12.05 \\
\hline $700^{\circ} \mathrm{C}$ & Carbon, C & 16.86 & 25.93 \\
\cline { 2 - 4 } & Oxygen, $\mathrm{O}$ & 51.56 & 59.52 \\
\cline { 2 - 4 } & Calcium, Ca & 31.58 & 14.55 \\
\hline $800^{\circ} \mathrm{C}$ & Carbon, C & 16.67 & 26.71 \\
\cline { 2 - 4 } & Oxygen, O & 46.03 & 55.38 \\
\cline { 2 - 4 } & Calcium, Ca & 37.29 & 17.91 \\
\hline $900^{\circ} \mathrm{C}$ & Carbon, C & 16.28 & 26.89 \\
\cline { 2 - 4 } & Oxygen, O & 42.52 & 52.72 \\
\cline { 2 - 4 } & Calcium, Ca & 41.21 & 20.40 \\
\hline
\end{tabular}

Based on the result, oxygen has highest weight $\%$ and atomic\% in all sample. This is due to the oxygen content in $\mathrm{CaCO}_{3}$ for uncalcined, $600^{\circ} \mathrm{C}$ and $700^{\circ} \mathrm{C}$ sample, $\mathrm{CaO}$ and $\mathrm{CaCO}_{3}$ in $800^{\circ} \mathrm{C}$ sample and $\mathrm{CaO}$ in $900^{\circ} \mathrm{C}$ sample. For $\mathrm{C}$ element, uncalcined sample have highest weight $\%$ and atomic\% of C. While at $900^{\circ} \mathrm{C}, \mathrm{Ca}$ element appeared it highest value at both weight $\%$ and atomic $\%$ at this sample. Based on this result, increasing of temperature caused atomic\% of Ca element increase and caused weight $\%$ of $\mathrm{C}$ element decrease.

\section{CONCLUSION}

From this study, it can be concluding that the physical and observation shows eggshell discoloration from black to white as increasing in calcination temperature. Apart from that, calcined eggshell at $900^{\circ} \mathrm{C}$ has the softest powder and less odor compare to other samples. IR spectra before calcinations shows wide stretching peaks attributing to $\mathrm{OH}$ vibrations from waste of residual in comparison to calcined IR spectra displays sharp absorption region of converted $\mathrm{CaO}$. In addition to that, the diameter of calcined particles will drastically have decreased with increasing in temperature. The calcination of $\mathrm{EW}$ that consist high $\mathrm{CaCO}_{3}$ produce $\mathrm{CaO}$ at temperature $900^{\circ} \mathrm{C}$ with XRD data of $2 \theta$ at: $32.2^{\circ}, 37.4^{\circ}$, $53.8^{\circ}, 64.1^{\circ}$ and $67.3^{\circ}$. Lastly, SEM images showed the morphology of EW structure have transformed from irregular flakes shaped to skeleton liked structure with confirmation of EDX that $\mathrm{EW}$ at $900^{\circ} \mathrm{C}$ consist of $\mathrm{CaO}$ with decreasing of $\mathrm{C}$ weight $\%$.

\section{ACKNOWLEDGEMENT}

This work was supported by Ministry of Higher Education (MOHE), Malaysia through Fundamental Research Grant Scheme (FRGS), FRGS/1/2019/TK05/UTHM/03/5, vote number K199; and Research Management Centre (RMC) UTHM through Graduate Research Grant (GPPS), vote number H540.

\section{REFERENCES}

J. Linden. Turn eggshell waste into a valuable resource, Wattagnet.com, July 2009. Accessed on : August 7, 2020. [Online]. Available : https://www.wattagnet.com/articles/743-turn-eggshellwaste-into-a-valuable-resource.

J. J. O. Afolayan, F. O. P. Oriola, G. Moses and J. E. Sani. Investigating the effect of eggshell ash on the properties of sandcrete block, International Journal of Civil Engineering, Construction and Estate Management, Vol. 5, no. 3, pp. 43-54, 2017.

N. Shiferaw, L. Habte, T. Thenepalli and J. W. Ahn. Effect of eggshell powder on the hydration of cement paste, Materials, Vol. 12, no. 15, pp. 1-12, 2019. 
4. G. Pandeeswari, G. R. Seenivasan, and V. Nandakumar. Experimental study on mechanical properties of waste concrete powder and coconut shell ash, International Journal of Emerging Technologies in Engineering Research (IJETER), Vol 7, no. 11, pp. 10-14, 2019.

5. A. Saji S. Shahana, S. Subahan, A. Thasneem, and A. Basheerudheen. Cost effective residential building using plastic bottles- a home for the future, International Journal of Emerging Technologies in Engineering Research (IJETER), Vol. 7, no. 6, pp. 5-13, 2019.

6. I. Abdulrahman, H. I. Tijani, B. A. Mohammed, H. Saidu, H Yusuf, M. N. Jibrin and S. Mohammed. From garbage to biomaterials: an overview on egg shell based hydroxyapatite, Journal of Materials, pp. 1-6, 2014.

7. A. Arabhosseini and H. Faridi. Application of eggshell wastes as valuable and utilizable products: a review, Research in Agricultural Engineering, Vol. 64, no. 2, pp. 104-114, 2018.

8. V. A. Apalangya, V. K. Rangari, B. J. Tiimob, S. Jeelani and T. Samuel. Eggshell based nano-engineered hydroxyapatite and poly(lactic) acid electrospun fiber as potential tissue scaffold, International Journals of Biomaterials, pp. 1-12, 2019.

9. S. Shearman. Scotch egg company claims to have cracked problem of eggshell waste, The Guardian.com, June 2016. Accessed on: August 7, 2020. [Online]. Available

https://www.theguardian.com/sustainable-business/2016 /June/30/scotch-egg-company-cracked-eggshell-waste-p roblem-recycling-plastic\#

10. R. Karpinski T. Jaworski and P. Czubacka. The structural and mechanical properties of the bone, Journal of Technology and Exploitation in Mechanical Engineering, Vol. 3, no. 1, pp. 43-50, 2017.

11. R. Setiawati and P. Rahardjo. Bone development and growth, Osteogenesis, pp. 1-21, 2018.

12. A. R. Yasmin and D. Kalyani. Naturally derived porous hydroxyapatite/polymer biocomposite of cuttlebone and eggshell for dental and orthopedic applications, International Journal of Research in Applied Science \& Engineering Technology (IJRASET), Vol. 3, no. 4, pp. 471-477, 2015.

13. C. Balaszi, G. Gergely, K. Balaszi, C. H. Chae, H. Y. Sim, J. Y. Choi, S. G. Kim. Bone formation with nano-hydroxyapatite from eggshell, Material Science Forum, Vol. 729, pp. 25-30, 2013.

14. R. Rohim, R. Ahmad, N. Ibrahim, N. Hamidin dan C. Z. A. Abidin. Characterization of calcium oxide catalyst from eggshell waste, Advances in Environmental Biology, Vol. 8, no. 22, 2014.

15. M. Horta, M. Aguilar, F. Moura, J. Campos, V. Ramos and A. Quizunda. Synthesis and characterization of green nanohydroxyapatite from hen eggshell by precipitation method, Materials Today: Proceedings, Vol. 14, pp. 716-721, 2019.

16. S. Hassanajili, A. K. Pour, A. Oryan and T. T. Khozani. Preparation and characterization of PLA/PCL/PHA composite scaffolds using indirect 3D printing for bone tissue engineering, Materials Science \& Engineering C, Vol. 104, pp. 1-13, 2019.

17. I. O. Oladele, O. G. Agbabiaka, A. A. Adediran. Structural performance of poultry eggshell derived hydroxyapatite based high density polyethylene bio-composites, Heliyon, Vol. 5, pp. 1-7, 2019.

18. T. Zaman, S. Mostari, Md. A. Al Mahmood and Md. S. Rahman. Evolution and characterization of eggshell as a potential candidate of raw material, Ceramica, Vol. 64, pp. 236-241, 2018.

19. Chapter 6, Building Envelope, pp. 310-317, 2017.

20. Chapter 11 - Heat treatment and chemical change. Elements in Abridge Science for High School Students from The Nuclear Research Foundation School Certificate Integrated, Vol. 1, pp. 11-18, 2012.

21. Y. Tsuboi and N. Koga. Thermal decomposition of biomineralized calcium carbonate: correlation between the thermal behavior and structural characteristics of avian eggshell, ACS Sustainable Chemistry \& Engineering, pp. 1-63, 2018.

22. C. H. Ashok, M. Kiran Kumar, C. H. Shilpa Cakra, K. Venkateswara Rao and T. Dayakar. Calcium oxide nano particles synthesized from chicken eggshells by physical method, Malla Reddy College of Engineering and Technology, pp. 72-75, 2014.

23. R. Rohim, R. Ahmad, N. Ibrahim, N. Hamidin dan C. Z. A. Abidin. Characterization of calcium oxide catalyst from eggshell waste, Advances in Environmental Biology, Vol. 8, no. 22, 2014.

24. R. Ahmad, R. Rohim and N. Ibrahim. Properties of waste eggshell as calcium oxide catalyst, Applied Mechanics and Materials, Vol. 754-755, pp. 171-175, 2015.

25. S. I. Biscaia, T. F. Viana, H. A. Almeida and P. J. Bartolo. Production and characterisation of PCL/ES scaffolds for bone tissue engineering, Materials Today: Proceedings, Vol. 2, pp. 208-216, 2015.

26. T. Viana, S. Biscaia, H. A. Almeida and P. J. Bartolo. PCL/eggshell scaffolds for bone regeneration, Proceedings of the ASME $201412^{\text {th }}$ Biennial Conference on Engineering System and Design and Analysis, pp. $1-6,2014$.

27. R. Mohadi, K. Anggraini, F. Riyanti, and A. Lesbani. Preparation calcium oxide from chicken eggshell, Sriwijaya Journal of Environment, Vol. 1, no.2, pp. 32-35, Nov. 2016.

28. J. Neunzehn, T. Szuwart, and H. P. Wiesmann. Eggshells as natural calcium carbonate source in combination with hyaluronan as beneficial additives for bone graft materials, an in vitro study, Head \& Face Medicine, Vol. 11, no. 1, pp. 1-10, July 2015. 
M. I. Najah et al., International Journal of Emerging Trends in Engineering Research, 8(10), October 2020, $6725-6731$

29. L. Habte, N. Shiferaw, D. Mulatu, T. Thenepalli, R. Chilakala, and J. W. Ahn. Synthesis of nano-calcium oxide from waste eggshell by sol-gel method, Sustainability, Vol. 11, no. 11, pp. 3196-3205, June 2019. 